\title{
The Implementation of E-Management Overview in Higher Education
}

\author{
Manap Somantri \\ Aan Komariah \\ Tonton T. Rahman \\ Dedy A. Kurniady \\ Bandung, Indonesia
}

Article History: Received: 10 November 2020; Revised 12 January 2021; Accepted: 27 January 2021; Published online: 5 April 2021

\begin{abstract}
This study aimed to formulate a quality model of e-management in higher education academic services. Through a qualitative approach, researchers conducted studies by means of spreading instruments. The qualitative results were deepened by conducting interviews with respondents at three universities, namely Pamulang University, Garut University, and Muhammadiyah Cirebon University. The research results obtained the following findings: 1) e-management planning has been going well; 2) support for the management system in the aspects of finance, access and network, as well as information documentation still needs to be improved; 3 ) the sustainability of e-management development has gone well when compared to handling non-conformities and corrective actions; 4) dimensions of internal audit, monitoring, assessment and evaluation analysis, as well as management reviews in the performance evaluation variable are carried out properly; and 5) the dimension of responsibility for the leadership variable still needs to be improved. The conclusion of this research was that planning arrangement is the dimension with the lowest respondent's perception compared to the other two dimensions, namely the combination of plan and plan design. In the aspect of management system support, it is clear that funding, access and networks, as well as documentation of information are perceived to be insufficient.
\end{abstract}

Keywords: e-management, higher education, ICT integration, Learning Management System

\section{Introduction}

The results of a survey conducted by the Indonesian Internet Service Providers Association in 2018 showed 13 sectors of internet users such as trade and services, education, government to the entertainment sector (Rohayani, 2015). The use of the internet for educational institutions is in the third place with $8.3 \%$. Internetbased technology integration in universities has become a necessity (Goverover, Y., Stern, B. Z., Hurst, A., \& DeLuca, 2021). However, it is different from several developing countries, including Indonesia. Integration of information technology systems into higher education governance systems is still limited, especially private universities (Y. F. Liu et al., 2014; Ali et al., 2020) The use of ICT has not become a fully integrated system in every function of governance of educational organizations, including in tertiary institutions (Ali et al., 2020; Lai \& Haleem, 2002). Only a small proportion of universities have fully optimized the function of ICT, for example for the management of the Learning Management System (LMS). Management functions that get support from internet-based information technology systems have not yet become a common pattern used in higher education governance systems. The use of the Internet by institutions such as education is still weak (Nonaka \& Takeuchi, 1995).

The issue of ICT integration into education is a clear strategy that causes confusion and decisions, potential losses from not being informed, decisions are not coordinated (Oye et al., 2011; Pituch \& Lee, 2006). The integration of technology-based systems into higher education governance has not been supported by an emanagement system that encourages changes from conventional to information technology-based in transition (Ogura et al., 2018). This integration affects the main activity, namely learning. The transition period is a critical period that can increase resistance and even decline the effectiveness of e-management operations in universities (Moon et al., 2014). The carrying capacity of information and communication technology governance in tertiary 
institutions is still considered weak in terms of planning, organizing, implementing and evaluation systems. Emanagement causes information and communication technology systems for teaching, research in universities to not run effectively (Conway et al., 2011).

The results of the pre-survey show that the weight of the websites that have learning content from 66 universities in Higher Education Service Institutions (LLDIKTI), West Java - Banten has the lowest score, only 3.57 indicates that the website is not used for the learning process. While the process of taking SKS has the highest average value, namely 4.22 , indicating that almost all college websites are for taking credits semester (SKS) and trusts. According to students, e-learning supports the learning process, has an average score of 4 . Not all college websites are equipped with the curriculum of each study program. The e-management is indispensable to ensure the quality of education and transform people as a resource. The e-management (e-administration) refers to behind-the-scenes information systems that support the management and administration functions of an institution, including data and information management, electronic record maintenance and information flow across departments (Laudon \& Laudon, 2014).

Research on e-management in tertiary institutions in the research environment continues to grow. Lai \& Haleem (2002) reveal issues in e-research that are related to the concept, design and model of implementing egovernance. Previously, Wirtz \& Daiser (2018) described e-governance research from various perspectives of information systems, organizational behavior and administration. A study of e-research in the field of education, especially administration is needed as an effort to obtain an explanation of the important aspects of the application of technology in administration. IT and e-management applications as studies in administration (Mitchell, 1993; Vatrapu \& Suthers, 2007).

To sum up, this study elaborated how e-management in private universities LLDIKTI West Java - Banten to encourage the quality of academic services at PTS throughout West Java - Banten with indicators in the form of variable planning, development, management, performance evaluation, leadership and quality service. The purpose of this study was to obtain a description and analyze e-management in private universities, LLDIKTI West Java - Banten. To encourage the quality of academic services at private colleges around LLDIKTI West Java - Banten. Specifically, the research objective is to analyze academic e-management in universities.

\section{Method}

This is a survey-based descriptive research which was conducted in West Java and Banten Indonesia to a number of higher educations which have applied e-management in their academic service process, namely Pamulang University, Muahammadiyah University of Cirebon, Garut University, High School of Technology Cirebon. Survey and descriptive analysis were used as initial research. The analysis in this study is used to obtain a description or description of e-management, which consists of leadership, planning, support of the service management system, performance evaluation and Quality Information academic system of LLDIKTI West Java - Banten.

To obtain data about the existence of e-management in higher education, researchers used questionnaires and interviews. The distribution of questionnaires carried out by the study was for 237 respondents from higher education which were used as research locus. Not all respondents provide responses and answers to the existence of e-management in higher education. Certainly, there were any data from 177 respondents which can be processed quantitatively were only. Therefore, respondents who did not provide answers were excluded from the analysis.

The responses were collected to be tested in accordance with the research objectives. Questionnaires to test the validity and reliability of the instruments were distributed within 2 weeks. Gradation of the respondents' answers is presented in table 1.

\section{Table 1}

Rating Scale

\begin{tabular}{ccc}
\hline NO & Answer Alternative & Score \\
\hline 1 & Very not adequate - very adequate & $1-5$ \\
\hline
\end{tabular}




\begin{tabular}{llr}
\hline 2 & Very not fulfilling - very fulfilling & $1-5$ \\
3 & Very not necessary - very necessary & $1-5$ \\
4 & Very not appropriate - very appropriate & $1-5$ \\
5 & Very vulnerable - very strong & $1-5$ \\
\hline
\end{tabular}

Respondents are seen as decision makers, formators, and implementers of e-management. Respondents are the Head of the IT Center, Academic Division, Head of Economics Study Program, Head of Management Study Program, Head of Accounting Study Program, Head of IT, IT Staff. The instrument was made using a Likert scale. The researcher collected sufficient question items relevant to problems under study and consisted of clear question items from negative to positive gradations. The question items were taken to a trial on a group of respondents who had almost the same characteristics as the actual sample. For qualitative data collection, it was given after determining results of the data processing from the questionnaires through in-depth interviews with respondents using snowball sampling on the respondents' source.

Table 2 Interview Guidance

\begin{tabular}{|l|l|l|}
\hline No & \multicolumn{1}{|c|}{ Questions } & \multicolumn{1}{c|}{ Indicators } \\
\hline 1 & What is the description of e- & Leadership, planning, Support of the service management system, Performance \\
management and & evaluation, Improvement
\end{tabular}

The data from the questionnaire results were analyzed from the results of central symptom measurement using statistical technique of mode (the most frequent value). The median and the mean are useful for describing the group based on the central symptom of the answer group using the excel program. While the results of the interview are in the form of memos, stated in the form of a description in this study.

\section{Literature Review}

\subsection{E-Management in Higher Education}

New technologies that are developing through the Internet of Things (IoT), have inspired universities to adopt and use them in solving management problems (Santoro et al., 2018). The use of internet in education management shows an application in dealing with knowledge management in higher education by a more open and collaborative application as well as by exploiting any necessary internal and external knowledge flows by higher education (Ali et al., 2020). By using E-manajemen, By using E-management, organizational activities are 
supported by up-to-date and continuous information, which can be monitored at any time, and managers receive early warning if any anomalies are found (Gunawan et al., 2012). E-management management as a system has functions and applications as well as institutional administrative operations that can handle, communicate and provide services to customers (Laudon \& Laudon, 2014 ; Laudon \& Laudon, 2014). E-management in practice has provided many benefits and has succeeded in making student learning in a more successful manner (Eraslan Yalcin \& Kutlu, 2019). By e-management, service provision for customers in more efficient co-administration perspective is easier, faster and at a lower cost (Pirni et al., 2019).

E-management is a flexible and open-to-exchange system of organizational governance and share influence with internal or external environment. E-management or electronic management has four components, namely, hardware, software, communication networks, and management concepts and mechanisms of their application that provide convenience in service by maximizing information technology functions (AbdelkarimAliEllatif \& Abdulmutalib, 2013). By e-management, it can obtain advantages in managing institutions, namely reducing error time, saving time and money, improving service quality, increasing economic competition, and increasing accountability (Foley \& Alfonso, 2009). The existence of e-management must be supported by strong leadership. Managers are encouraged to accelerate the implementation of e-management with e-leadership. E-leadership talks about combining technology and traditional communication as well as using more ICT-mediated communication that has been used in e-management (Van Wart et al., 2019).

E-management in higher education is started to be massively applied along by the development of information and communication technology (Simeon Adebayo \& Maruff Akinwale, 2016). Task complexity, efficiency demand and improvement of competence are seen as a consideration to design more efficient management by utilizing development of information technology. E-management requires the use of ICT to conduct the managerial functions such as planning, organizing, staffing, leading or directing, and controlling organization to achieve organizational goals (Simeon Adebayo \& Maruff Akinwale, 2016). E-management is a strategic approach in organizational governance having orientation to the future and to be dynamics by applying high performed technology (Simeon Adebayo \& Maruff Akinwale, 2016). E-management made by higher education should integrate among aspects for automatization and should optimize artificial intellegence function through rapidity of system development to achieve organizational vision (Yao, L., Othman, A. B., Aballama, A. N., \& Mahdi, 2011).

\subsection{Implementation of E-Management by E-Leadership.}

E-leadership addresses to combine technology and traditional communication as using more communication which is mediated by ICT used previously in e-management (Van Wart et.al., 2019). Emanagement in higher education is started to be massively applied along by the development of information and communication technology (Simeon Adebayo \& Maruff Akinwale, 2016). Task complexity, efficiency demand and improvement of competence are seen as a consideration to design more efficient management by utilizing development of information technology. E-management requires the use of ICT to conduct the managerial functions such as planning, organizing, staffing, leading or directing, and controlling organization to achieve organizational goals (Simeon Adebayo \& Maruff Akinwale, 2016). E-management is a strategic approach in organizational governance having orientation to the future and to be dynamics by applying high performed technology (Simeon Adebayo \& Maruff Akinwale, 2016). E-management made by higher education should integrate among aspects for automatization and should optimize artificial intellegence function through rapidity of system development to achieve organizational vision (Yao, Othman, Aballa, \& Omar,2011)

\section{Results and Discussion}

\subsection{Description on e-Management Planning}

Planning is carried out in a participatory manner, with the support of quality management methods and tools. The description of the research results, from the planning variable, shows that the three dimensions studied in this study were perceived differently by respondents. The following is a description of the planning variables in question. 


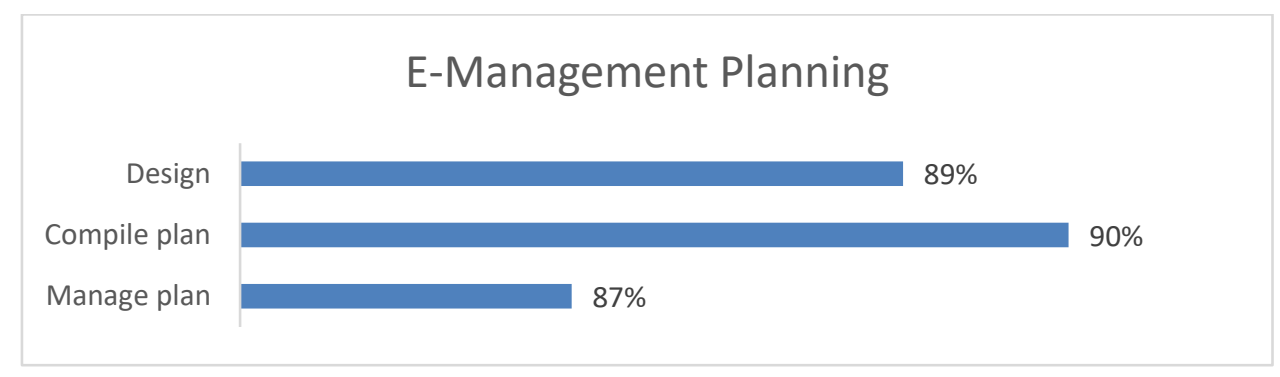

Figure 1. Description on e-Management Planning

Of the three dimensions studied, manage plan from respondents' answers is the dimension with the lowest respondent compared to the other two dimensions, with $87 \%$ and it is in the good category. Meanwhile, the compile plan according to the respondents' answers is included in the very good category, namely $90 \%$. As for the design dimensions, with a size of $89 \%$ it is also included in the very good category. If you look at the results above, it can be interpreted that management planning is currently in accordance with the goals and expectations of the user, and is carried out based on existing management mechanisms, including: 1) problem identification analysis, 2) identification of facilities and resource availability Institutions, 3) validation of human resources, 4) the existence of a defined procedure to implement planning, and 5) scheduling of the implementation program and validation of planning revisions.

The results of interviews with a number of informants also show the similarity of information, that the emanagement planning process is carried out through a needs analysis, then the results of the analysis are continued to the design stage to the implementation carried out by the developer. Planning carried out also involves a team of experts (external) in designing e-management, as well as paying attention to the resources needed in emanagement, including computer networks and the internet, computer hardware. In preparing the management plan, the section or unit responsible for this is the Directorate of Technology and Information Systems (DTSI) under the coordination of the director of facilities and infrastructure.

E-management planning in a number of campuses is carried out by involving external parties (experts) who have the capacity to realize the desired management. This effort is made when internal HR competencies do not support the expected e-management development. As the informant conveyed that in terms of human resource support, the leadership did not involve internal human resources because in the development of campus emanagement using external parties, and external parties were only involved in the first year. Resource requirements in e-management include competent human resources in the field of information technology, work units and facilities such as offices, servers, PCs, fiber optics, wifi networks, and funding allocated for development and maintenance.

Planning for e-management budget requirements is tailored to the needs of management development and also for periodic e-management maintenance. The e-management budget planning is carried out on a bottom-up basis through the DTSI Unit. This unit is in charge of making an annual cost plan and periodically evaluating the allocation for procurement, maintenance, and improvement of the quality of human resources. Information processing in e-management shows that a number of input instruments are needed to be processed into information that will be sent to users, namely students. Input data / information according to the needs and features available in e-management. College contracts, tuition payments, UTS and UAS examination activities, lecturer data for courses are input instruments in e-management on this campus. In addition, the input instrument is also related to the performance of lecturers related to the implementation of the Tridarma of higher education, student management, room management and facilities. Higher education institutions that have limited human resource constraints, in e-management planning, are more like an input instrument than in the e-management development process. Inputs submitted by the academic community, both from study programs and lecturers, are conveyed to the developer to be followed up, including technical problems.

"The involvement of study programs and lecturers is only limited to input and criticism, not involved in designing e-management. The time needed to realize the e-management design is approximately 2 years, 
and a planned schedule (time schedule) in implementing the e-management plan. Even though until now there has been no re-evaluation of the plans for the previously made e-management design." - (design EM)

The obstacle found in one of the tertiary institutions in developing e-management is data synchronization and integration. Synchronizing existing data in tertiary institutions with those listed in PDDIKTI is still a major obstacle. E-management, which is currently found in a number of universities, has not yet synchronized data, so it needs to be addressed. The root of this problem occurs when the campus, either developing e-management independently or from the developer, is not integrated with existing data in the Ministry of Research, Technology and Higher Education. Or in other words do not have access rights to big data in the DIKTI feeder. This consequence has an impact on the double work of IT staff, who have to input the e-management on the campus itself and also the DIKTI feeder. The development of e-management has not been integrated (has links) with other existing systems or systems that are currently being developed, including integration with systems outside agencies (such as DIKTI, e-pusnas, etc.).

In the context of planning management, the other major issues related to quality management. Planning is a strategic effort to shorten the product development cycle (Evans \& Ali, 2013). The e-management design on each campus is different, tailored to the needs and comfort of the leaders in executing existing information. The convenience is not only when the user enters information. The output from management must also be able to provide representative information for leaders, so that it can be used as a basis for future quality-oriented academic decision making (Chien, 2012; Zerihun et al., 2011). The current rapid development of IT enables universities to develop e-management that is compatible with various types of hardware and software (Hofstede, 1991). If in the previous decade e-management was developed limited to PCs, in the present era e-management can be accessed via Android and smartphone devices. In general, the existing e-management interface is easy to understand and use (Donahue \& Glodstein, 2013; Ranjan et al., 2012).

The ability to access via smartphone and android based makes it easy for users to access information and also input the required data. Students no longer rely on PC devices just for conducting lecture contracts, mentoring, and viewing learning outcomes, and other activities. For lecturers too, if previously input grades were carried out in conventional form (through paper), with e-management that allows existing devices to access, then this work process can be done quickly and where it can be done (Bhaumik, 2012; Davis, 2016).

\subsection{Management System Support}

A number of these components support the e-management business process that are interrelated with one another. Based on the results of respondent data processing, with regard to management system support by measuring the components above, it is obtained an illustration that there are three components that are perceived as inadequate in supporting the implementation of e-management. The three components are: 1) budget (funding) with a percentage of $87.4 \% ; 2$ ) access and network (coverage and network) with a percentage of $87.4 \%$, and 3) documentation of information with a percentage of $87.3 \%$. The overall description of the components of the support of the service management system can be seen in Figure 2.

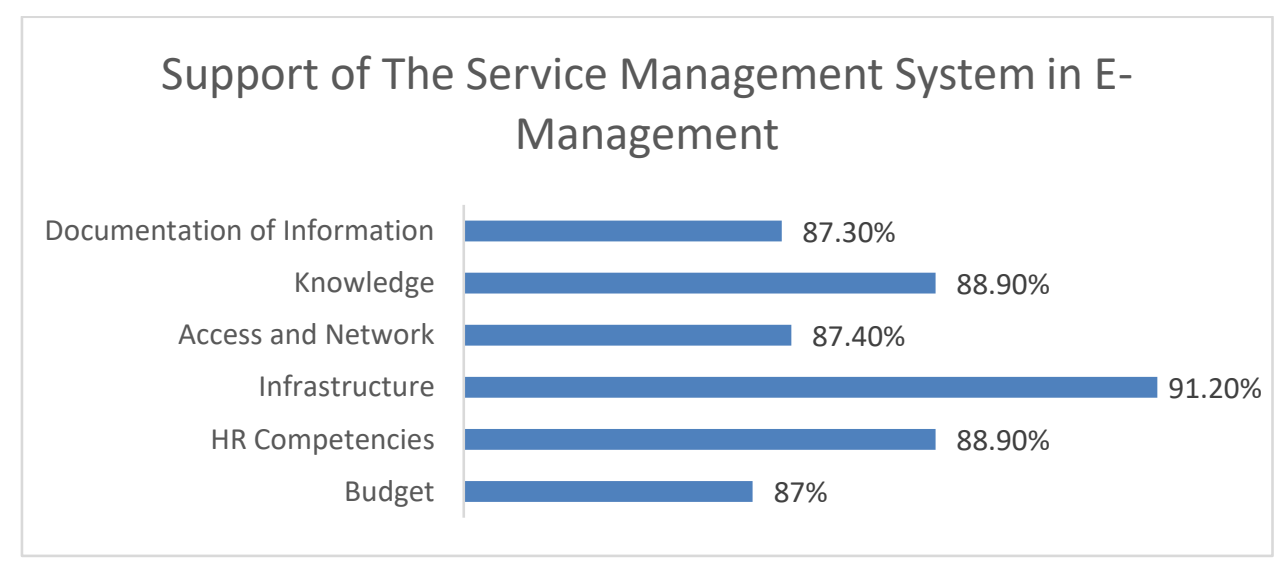

Figure 2. Description on Management System 
Based on the chart above, other information that can be explained is that the infrastructure component in respondents' perceptions has met and supports the implementation of e-management, with a percentage of $91.2 \%$. Then in the component of human resource competence and the component of knowledge (knowledge) is also perceived by the respondents, namely that they have fulfilled and supported the implementation of e-management of academic services with a percentage of $88.9 \%$ each.

The results of the research findings indicated that universities with adequate funding support were richer in e-management features compared to universities with minimal funding. The features developed in emanagement include Official email, SSO (Single Sign On), SIAT (Integrated Academic Information System), Blog, Forum, SMS Broadcast, E-content Downloader, about Universities, News, Education, Academic, Facilities, Services online, PMB online, Web Institute, e-learning, Sinta, Sister and journals. The complete importance of funding in e-management was conveyed by the informants as follows.

"Certainly funding (fees) owned by the campus will determine the development of e-management. The more features that are developed, the more funds are needed, the main allocation for learning facilities / infrastructure such as servers / cloud servers, official email, bandwidth, and personnel spending." (develop EM).

The cost requirements in e-management are not only for input instruments, such as infrastructure and personnel spending. Maintenance and management development also requires sufficient funding. Risk appears as a system failure problem that requires special expertise and future from external parties. Constraints related to funding are indeed a crucial element facing universities today that want to improve the quality of academic services through e-management. For universities with minimal funding, as found in the field, there are alternative solutions that can be offered, namely by asking for external services that provide special package services for the implementation of e-management in universities.

These efforts were taken when the funding was minimal and there were limited human resources who were experts in the IT field. On the one hand, the expert makes it easy for universities, but there are still limitations in terms of features, because usually the features offered are in packages and have been "given" according to the budget size. Another convenience is when universities that use this solution are no longer burdened with maintenance and technical repairs when problems occur. The higher education institution only needs to report it from external parties (vendors) who will follow up on complaints.

Support of organizational resources in implementing e-management of academic services is needed so that business processes run with their functions (Dedoussis, 2004). The aim of e-management is to accelerate higher quality academic services and provide satisfaction to users. In addition, another function is top management's information in making policies and deciding quickly and precisely when problems occur in service (Davis, n.d.). Organizational support includes a number of components that interact directly, such as: e-management funding, existing human resource competencies, e-management supporting infrastructure, knowledge, access and networks, and information documentation (Cooke \& Szumal, 1993; Johnston et al., 2005; Mahdizadeh et al., 2008).

Funding is a crucial component in the development of e-management of academic services in higher education (Francescato et al., 2006; Grigoraş et al., 2014; Hofstede, 1991). The amount of the budget greatly determines the quality of the e-management developed. With a large budget, universities can develop a variety of service features and quality infrastructure procurement so that they can support the implementation of good university governance. In addition, with the availability of adequate budgets, capital expenditures can be carried out, namely by recruiting employees with competent competencies in the field of e-management development. So that the orientation of e-management development is not only limited to the fulfillment of academic administration alone, but also to increase the value (value added) and competitive advantage of higher education (Evans \& Ali, 2013).

Development of e-management by involving external parties makes it easier for higher education institutions in terms of time and energy (Simon \& Ward, 2019). Efficiency and effectiveness can be obtained, without having to spend a lot of internal manpower and without having to recruit special personnel to handle 
management development and maintenance. Feature development can also be done if the existing features do not meet the needs of the tertiary institution. Universities using external services only need to provide infrastructure support such as Wi-Fi and bandwidth. The use of external services is not without shortcomings. Apart from being expensive for development and maintenance, the response to repairs and handling of complaints is also sometimes slow, considering that handling must wait from external parties. It is different from universities which specifically have IT personnel and develop e-management applications independently.

\subsection{Improvement on e-Management}

E-management development as a system is defined as an effort to encourage service processes to be more effective and efficient. Academic services are better able to produce good quality in each process and output that is carried out continuously. Two dimensions that become the study of this research with regard to improvement in e-management, namely continual improvement and nonconformity and correction action show that there are differences in perception. Respondents' perception of continual improvement was better than improvement in the form of non-confirmation and correction action. A percentage of $89.8 \%$ indicates that so far development in emanagement has been more of a continuous or periodic development, rather than improvement as a follow-up to incidental problems.

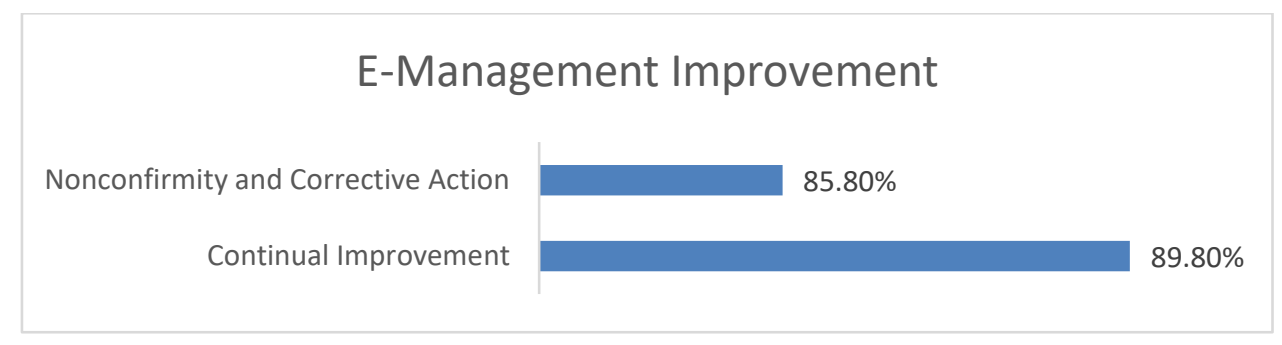

Figure 3. Description on e-Management Improvement

If we look at the results above, it can be interpreted that the development of management in higher education is currently more about meeting internal needs, especially from the leadership element. This can be understood because universities in this effort have limited funding and competent human resources in the field of e-management development. E-management as a management tool that allows academic service processes to be provided quickly and accurately, in principle, is something static or permanent as long as the current functions/features can accommodate the needs of users and leaders. as long as the management function is running normally, it is unlikely that incidental development will be carried out so that it will run incrementally. Emanagement development also requires time and skills updating from IT personnel. The process does not run briefly, takes a long time and is a trial-and-error process which sometimes creates new risks to e-management designs that have been used previously (Sörlin \& Vessuri, 2007; Vandenhouten et al., 2014).

"Development is carried out every semester in the form of updating / improving the e-management system. This process requires proper planning and timing so that its success can be executed properly." (improvement EM)

The success in increasing the fulfillment of user satisfaction is based on a continuous process of quality improvement and cost reduction that makes the institution superior compared to other institutions (Francescato et al., 2006).

Success in e-management development is closely related to development plans. The development plan contains a number of aspects, including feature improvements, new knowledge and skills requirements, data synchronization and data backup, report output, interface adjustments, to socialization at the technical level (Tulinayo et al., 2018). It is not a simple matter when universities want to carry out development in e-management considering that everything must be planned carefully. For tertiary institutions that use external parties, this form of e-management development is not a significant obstacle. In adding features, for example, universities only need to ask vendors to add the desired features and organize training for a number of parties (IT staff and lecturers) to attend training conducted as a form of updating knowledge (Takeuchi, 2006). 


\subsection{Performance Evaluation}

The results of the research through the distribution of instruments showed that from the four indicators studied, internal audit and monitoring, measurement analysis and evaluation, and management review were perceived as adequate by respondents in e-management. Internal audit with a percentage of $81.5 \%$ and monitoring, measurement analysis and evaluation with a percentage of $82 \%$ and $83.8 \%$ on management review. In full, these results are presented in the graph in Figure 4.

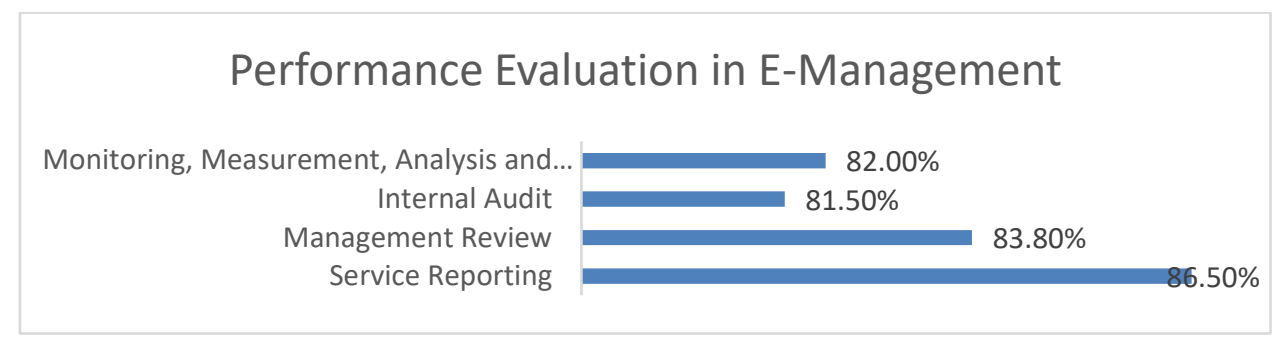

Figure 4. Description on Performance Evaluation

Performance evaluation is a form of monitoring the effectiveness and efficiency of the governance system. The e-management performance evaluation is an important aspect that can encourage improvement in the quality of academic services (Mitchell, 1993; Vatrapu \& Suthers, 2007). The e-management evaluation is carried out as part of governance using a variety of approaches, including measuring various indicators using valid and reliable measuring tools to assess success and achievement.

Based on the chart above, the service reporting indicator is the indicator with the highest perception of respondents with $86.5 \%$. Service reporting is the ability of e-management to present complete data and can help users and leaders obtain the required information. Looking at the percentage, it is indicated that the service reporting produced by e-management currently has met the expectations of all parties (Conway et al., 2011; Moya et al., 2011). The findings of the tertiary institutions studied, service reporting which is the output of emanagement, are of various forms according to the completeness of existing features (Pituch \& Lee, 2006). In universities that independently develop e-management, service reporting has reached top management utilization in the form of DDS (Decision Support System) and ESS (Executive Support System) (Y. F. Liu et al., 2014).

Providing quality academic services requires excellent and stable e-management, so a management review in this case is needed. through this function, deficiencies can be identified and corrective action can be taken immediately. Duplication of data or double data is the condition of the data recorded in e-management that exceeds the input that should be, or in simple terms, there is a data equation in e-management. Queries developed in management generally input each character, and when these characters are recorded in the database even though the code / name is the same. The e-management system continues to process it into another or separate piece of data. The first error usually appears from the initial input or initial data entry, and is followed by the next input. To minimize the above constraints, it can be done through internal audit actions conducted by SPMI. SPMI as an internal quality assurance unit must be able to provide a certainty that e-management can be carried out according to its function, and detect early indications of problems in e-management utilization, including indications of problems that arise due to human errors.

\subsection{Leadership on E-Management}

The results of the research through the distribution of instruments show that of the five dimensions studied, the responsibility of leaders in developing e-management has not met ideal expectations, compared to other dimensions such as commitment, authority, organization role and policy. A complete picture, of these variables can be seen in Figure 5. 


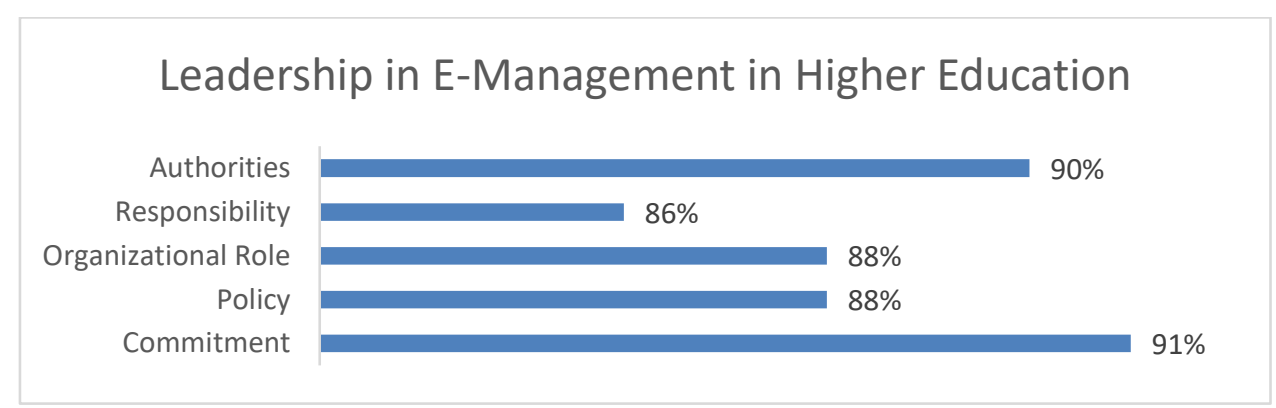

Figure 5. Description on Leadership

The graph above provides information that the leadership's commitment in developing e-management and authority running in tertiary institutions has met the expectations of users, especially students, with a percentage of $91 \%$ in commitment and $90 \%$ on authorities. Respondents perceive e-management as something positive and able to accommodate needs, especially in academic services. In its implementation, there is also clarity in the division of tasks and responsibilities so that it makes it easier for users to submit suggestions, input and complaints if there are obstacles in using e-management.

Leaders are a determining factor in the success or failure of an organization, both in the world of business and in the world of education (Kohl et al., 2012). A leader will determine how a decision is taken, especially at a critical moment, on the other hand, decisions can be made democratically or based on consensus for the benefit of the organization (S. Liu et al., 2016). A leader has the ability to move other people, subordinates to take action as desired. Leaders are required to be able to overcome problems faced by the institution and to have a clear vision of the form or existence of the organization in the future. The leader is a determinant of success in managing the Institute.

The dimensions of policy and organization role were perceived by respondents in the adequate category with $88 \%$ each. Policy relates to policies set by the leader in implementing e-management, including those that form the basis of procedures and mechanisms for utilization of management. Meanwhile, in the rules of the organization (organization role), also regulates the rights and obligations as well as the procedures for using emanagement itself. The dimension of responsibility becomes the dimension with the lowest percentage, namely $86 \%$. This dimension examines the responsibility of the leader in implementing management and the development of the features in it. If you look at the percentage, there are things that have not been accommodated in the perceptions of respondents by the current leader in e-management. An indication of why this is happening is the lack of socialization on the use of management from the leadership to the user and the lack of documents related to e-management, such as guidelines for using e-management.

"The rules regarding reward and punishment for study programs and study program lecturers do not implement e-management (for example, lecturers who do not want to use e-management or study programs who are late in reporting e-management) have not yet existed, or have not been made." - (Implement EM)

The leadership's commitment to e-management development plays an important role in maintaining the effectiveness and efficiency of academic services in higher education. This is because there are more and more demands from users (students and lecturers) for information acceleration (Moore \& Benbasat, 1991; Rogers, 2010). The form of leadership commitment also relates to the development of e-management features. Features in e-management of academic services must be able to integrate with other fields / components, such as finance, infrastructure, and supporting facilities for lectures so that the overall functions of university components run harmoniously.

\subsection{The e-Management Quality of Academic Services}

The six dimensions show the diversity of respondents' perceptions in Figure 6. 


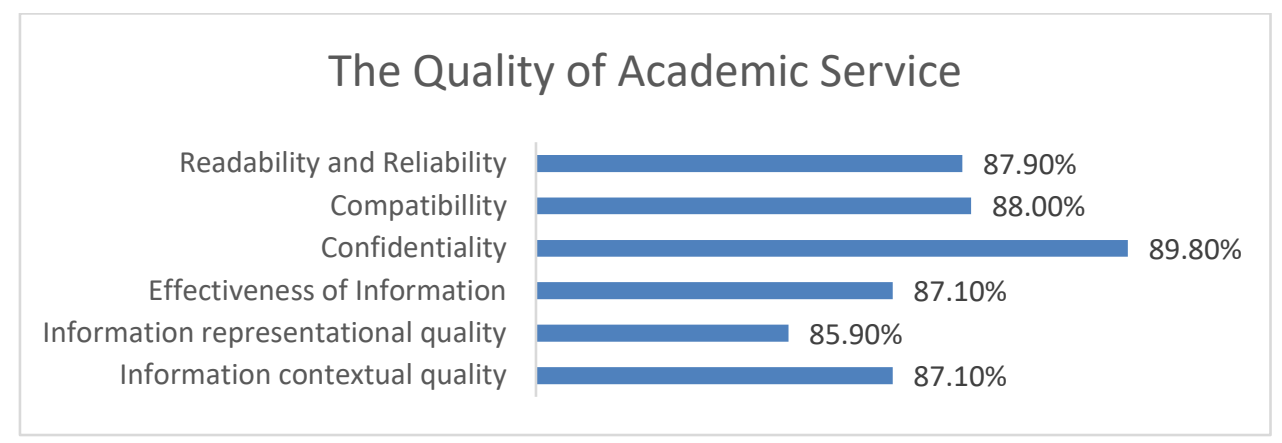

Figure 6. Description on the Quality of Academic Service

Respondents perceive the representational quality information dimension still needs to be improved, namely by $85.9 \%$. Whereas in another dimension, the respondent's perception can be said to have fulfilled the academic service received. The dimension that received a very adequate perception was the effectiveness of information, namely $89.8 \%$. This percentage indicates that universities are able to deliver academic information well to users (students) through existing e-management. The dimensions of information contextual quality were also responded adequately by respondents with $87.1 \%$. This dimension measures the extent to which the information that occurs in e-management meets user needs in accordance with existing conditions or expected needs.

The fullness of information in e-management makes it easy for users to capture the messages conveyed, so that there is no mistake of understanding. Updating information is very necessary in this process, and needs to be done regularly through existing e-management features. For example, when there is information about changes in campus academic agendas, changes in academic policies, and other information that directly touches students. If this kind of information can be received quickly, it will foster student trust and satisfaction with the institution. Field findings show that when institutions are able to provide representative information to students, satisfaction with the institution increases. Through e-management this process can be done quickly and easily, thereby saving time and students' labor in obtaining the information they need.

"There was an increase in students enrolling when using management. Because of the ease of registering and all information is displayed on the website. Prospective applicants do not have to come to campus, just by opening the PMB website, registration can be done." - V6.W.R01

The quality of e-management of academy services illustrates how a quality service system integrates technology in the process and in its delivery (Yıldız \& Beşoluk, 2019). As a result of a combination of many factors, the quality of academic services collaborates each individual performance into a single unit. The combination of human performance and e-management systems can produce more satisfaction scores from users. There are six dimensions measured in this regard in this study (Rumanyika \& Galan, 2015).

From the aspect of coverage, the e-management used in a university can be said to have been able to accommodate all needs, both users (lecturers and students) and leaders. The needs of users, especially students, are more for information on learning outcomes and lecture services (Harris, 2018). The limitation of features in e-management in higher education is a factor that hinders reach. If studied in depth, feature limitations occur due to minimal funding factors in e-management development so that universities can only meet the administrative needs of academic services. With current technological advances, e-management can be developed into a more complex form and can reach all academicians, including alumni and university stakeholders (Kottemann et al., 2018).

\section{Conclusion}

Based on the results of the research that has been done, the conclusion can be conveyed that the implementation of e-management of academic services in private college around LLDIKTI West Java - Banten in the aspect of e-management planning is currently in accordance with the goals and expectations of the user, and is carried out based on management mechanisms which exists. Sustainable development is better than 
development in the form of non-conformity and corrective action. Development in management in higher education is currently more about meeting internal needs, especially from the leadership element. Features in emanagement of academic services must be able to integrate with other fields/components, such as finance, infrastructure, and lecture support facilities so that the overall functions of higher education components run harmoniously. The quality of academic services, respondents perceive the dimensions of information representation have not met expectations. The fullness of information in e-management makes it easy for users to capture the messages conveyed, so that there is no mistake of understanding. Updating information is very necessary in this process, and needs to be done regularly through existing e-management features.

\section{References}

[1]. Simeon Adebayo, O., \& Maruff Akinwale, O. (2016). Students' E-Management Variables and University Administration Effectiveness in Nigeria: Policy Orientations. Malaysian Online Journal of Educational Management, 4(2). https://doi.org/10.22452/mojem.vol4no2.1

[2]. AbdelkarimAliEllatif, H., \& Abdulmutalib, S. (2013). E-Management; Configuration, Functions and Role in Improving Performance of Arab Institutions and Organization. International Journal of Computer Applications, 80(6). https://doi.org/10.5120/13868-1727

[3]. Ali, E. Y., Munir, M., Permana, J., \& Kurniady, D. A. (2020). Academic Service Quality in Education Management in Higher Education. https://doi.org/10.2991/assehr.k.200130.221

[4]. Bhaumik, P. K. (2012). Use of ICT in the classroom teaching of management. Vision, 16(4), 245-252.

[5]. Chien, T. (2012). Computer self-efficacy and factors influencing e-learning effectiveness. European Journal of Training and Development.

[6]. Conway, M., Munguatosha, G. M., Muyinda, P. B., \& Lubega, J. T. (2011). A social networked learning adoption model for higher education institutions in developing countries. On the Horizon.

[7]. Cooke, R. A., \& Szumal, J. L. (1993). Measuring normative beliefs and shared behavioral expectations in organizations: The reliability and validity of the Organizational Culture Inventory. Psychological Reports, 72(3_suppl), 1299-1330.

[8]. Davis, F. D. (n.d.). Perceived usefulness, perceived ease of use, and user acceptance of information technology. MIS Q. 13 (3), 319 (1989).

[9]. Dedoussis, E. (2004). A cross-cultural comparison of organizational culture: evidence from universities in the Arab world and Japan. Cross Cultural Management, 11(1), 15-34.

[10]. Donahue, N., \& Glodstein, S. (2013). Mentoring the needs of nontraditional students. Teaching and Learning in Nursing, 8(1), 2-3.

[11]. Eraslan Yalcin, M., \& Kutlu, B. (2019). Examination of students' acceptance of and intention to use learning management systems using extended TAM. British Journal of Educational Technology, 50(5). https://doi.org/10.1111/bjet.12798

[12]. Evans, M. M., \& Ali, N. (2013). Bridging knowledge management life cycle theory and practice. International Conference on Intellectual Capital, Knowledge Management and Organisational Learning ICICKM 2013-Conference Proceedings, 156-165.

[13]. Foley, P., \& Alfonso, X. (2009). eGovernment and the transformation agenda. Public Administration, 87(2). https://doi.org/10.1111/j.1467-9299.2008.01749.x

[14]. Francescato, D., Porcelli, R., Mebane, M., Cuddetta, M., Klobas, J., \& Renzi, P. (2006). Evaluation of the efficacy of collaborative learning in face-to-face and computer-supported university contexts. Computers in Human Behavior, 22(2), 163-176.

[15]. Goverover, Y., Stern, B. Z., Hurst, A., \& DeLuca, J. (2021). Internet-based technology in multiple sclerosis: Exploring perceived use and skills and actual performance. Neuropsychology, 35(1), 69-77.

[16]. Grigoraş, G., Dănciulescu, D., \& Sitnikov, C. (2014). Assessment criteria of e-learning environments quality. Procedia Economics and Finance, 16, 40-46.

[17]. Gunawan, A., Wahdan, M. A., Herik, H. J. Van den, Kornarius, Y. P., \& Walle, B. Van de. (2012). Can e-management improve the Indonesian SMEs? International Journal of Trade and Global Markets, 5(3/4). https://doi.org/10.1504/ijtgm.2012.049985

[18]. Harris, C. W. (2018). The lecture is dead, long live the lecture! JALT, l(2), 63. 
[19]. Hofstede, G. (1991). Cultures and organizations: Software of the mind (london and new york, McGraw hill). House, RJ, Hanges, PJ, Javidan, M., Dorfman, PW, \& Gupta, V.(Eds. 2004), Airaksinen, 1-25.

[20]. Johnston, J., Killion, J., \& Oomen, J. (2005). Student satisfaction in the virtual classroom. Internet Journal of Allied Health Sciences and Practice, 3(2), 6.

[21]. Kohl, H. W., Craig, C. L., Lambert, E. V., Inoue, S., Alkandari, J. R., Leetongin, G., Kahlmeier, S., Andersen, L. B., Bauman, A. E., Blair, S. N., Brownson, R. C., Bull, F. C., Ekelund, U., Goenka, S., Guthold, R., Hallal, P. C., Haskell, W. L., Heath, G. W., Katzmarzyk, P. T., ... Wells, J. C. (2012). The pandemic of physical inactivity: Global action for public health. In The Lancet (Vol. 380, Issue 9838, pp. 294-305). Lancet Publishing Group. https://doi.org/10.1016/S0140-6736(12)60898-8

[22]. Kottemann, P., Plumeyer, A., \& Decker, R. (2018). Investigating feedback effects in the field of brand extension using brand concept maps. Baltic Journal of Management.

[23]. Lai, R., \& Haleem, A. (2002). E-governance: an emerging paradigm. Vision, 6(2), 99-109.

[24]. Laudon, K. C., \& Laudon, J. P. (2014). Management Information Systems: Managing the Digital Firm (13th Editi). Edinburgh: Pearson Education Limited.

[25]. Liu, S., Hallinger, P., \& Feng, D. (2016). Supporting the professional learning of teachers in China: Does principal leadership make a difference? Teaching and Teacher Education, 59, 79-91.

[26]. Liu, Y. F., Xie, D., \& Yuan, Y. J. (2014). A Research in Knowledge Management System for the Development of DSS. Advanced Materials Research, 945, 3037-3040.

[27]. Mahdizadeh, H., Biemans, H., \& Mulder, M. (2008). Determining factors of the use of e-learning environments by university teachers. Computers \& Education, 51(1), 142-154.

[28]. Mitchell, M. (1993). Situational interest: Its multifaceted structure in the secondary school mathematics classroom. Journal of Educational Psychology, 85(3), 424.

[29]. Moon, M. J., Lee, J., \& Roh, C.-Y. (2014). The evolution of internal IT applications and e-government studies in public administration: Research themes and methods. Administration \& Society, 46(1), 3-36.

[30]. Moore, G. C., \& Benbasat, I. (1991). Development of an instrument to measure the perceptions of adopting an information technology innovation. Information Systems Research, 2(3), 192-222.

[31]. Moya, M., Musumba, I., \& Akodo, R. (2011). Management attitude, support and integration of information communication technologies in higher education in Uganda. Journal of Modern Accounting and Auditing, USA, ISSN: 1548-6583.

[32]. Nonaka, I., \& Takeuchi, H. (1995). The knowledge-creating company: How Japanese companies create the dynamics of innovation. Oxford university press.

[33]. Ogura, A., Hayashi, N., Negishi, T., \& Watanabe, H. (2018). Effectiveness of an e-learning platform for image interpretation education of medical staff and students. Journal of Digital Imaging, 31(5), 622627.

[34]. Oye, N. D., Noorminshah, A., \& Rahim, N. A. (2011). Examining the effect of technology acceptance model on ICT usage in Nigerian tertiary institutions. Journal of Emerging Trends in Computing and Information Sciences, 2(10), 533-545.

[35]. Pirni, A., Giampellegrini, P. P., \& Raffini, L. (2019). Digital transformation and egovernment. For a research agenda on the Liguria region. OBETS, 14(2). https://doi.org/10.14198/OBETS2019.14.2.07

[36]. Pituch, K. A., \& Lee, Y. (2006). The influence of system characteristics on e-learning use. Computers \& Education, 47(2), 222-244.

[37]. Ranjan, J., Boyle, B., McDonnell, A., Mitchell, R., \& Nicholas, S. (2012). Managing knowledge in internationalizing universities through foreign assignments. International Journal of Educational Management.

[38]. Rogers, E. M. (2010). Diffusion of innovations. Simon and Schuster.

[39]. Rohayani, A. H. H. (2015). A literature review: readiness factors to measuring e-learning readiness in higher education. Procedia Computer Science, 59, 230-234.

[40]. Rumanyika, J. D., \& Galan, R. M. (2015). Challenges for teaching and learning information and communication technology courses in higher learning institutions in Tanzania: A review.

[41]. Santoro, G., Vrontis, D., Thrassou, A., \& Dezi, L. (2018). The Internet of Things: Building a knowledge management system for open innovation and knowledge management capacity. Technological Forecasting and Social Change, 136. https://doi.org/10.1016/j.techfore.2017.02.034 
[42]. Simon, C. A., \& Ward, S. (2019). A Student's Guide to Education Studies: A Student's Guide. Routledge.

[43]. Sörlin, S., \& Vessuri, H. (2007). Knowledge society vs. knowledge economy: Knowledge, power, and politics. Springer.

[44]. Takeuchi, H. (2006). The new dynamism of the knowledge-creating company. Knowledge Economy, 1, $1-10$.

[45]. Tulinayo, F. P., Ssentume, P., \& Najjuma, R. (2018). Digital technologies in resource constrained higher institutions of learning: a study on students' acceptance and usability. International Journal of Educational Technology in Higher Education, 15(1), 36.

[46]. Van Wart, M., Roman, A., Wang, X. H., \& Liu, C. (2019). Operationalizing the definition of eleadership: identifying the elements of e-leadership. International Review of Administrative Sciences, 85(1). https://doi.org/10.1177/0020852316681446

[47]. Vandenhouten, C., Gallagher-Lepak, S., Reilly, J., \& Ralston-Berg, P. (2014). Collaboration in ELearning: A Study Using the Flexible E-Learning Framework. Online Learning, 18(3), n3.

[48]. Vatrapu, R., \& Suthers, D. (2007). Culture and computers: A review of the concept of culture and implications for intercultural collaborative online learning. International Workshop on Intercultural Collaboration, 260-275.

[49]. Wirtz, B. W., \& Daiser, P. (2018). A meta-analysis of empirical e-government research and its future research implications. International Review of Administrative Sciences, 84(1), 144-163.

[50]. Yao, L., Othman, A. B., Aballama, A. N., \& Mahdi, O. R. (2011). E-management development and deployment strategy for future organization. African Journal of Business Management, 5(16).

[51]. Yıldız, Ş., \& Beşoluk, Ş. (2019). The Investigation of the Effect of Problem Based Teaching Approach on Students' Problem Solving Skills and Academic Achievements in Science Course.

[52]. Zerihun, Z., Beishuizen, J., \& Van Os, W. (2011). Conceptions and practices in teaching and learning: implications for the evaluation of teaching quality. Quality in Higher Education, 17(2), 151-161. 